\title{
A Theoretical Debate and Strategy to Link Structure and Agency in Policy Process Studies: A Network Perspective
}

\author{
Guang-Xu Wang \\ Department of Public Administration and Management \\ National University of Tainan, Taiwan \\ E-mail: guangxu.wang@gmail.com
}

\begin{abstract}
Questions of policy formation/implementation are often translated into the language of power, and the policy process is undoubtedly a political issue rather than a technical issue. Studies of the policy process are used to apply either a structural or individual perspective to explain power distribution in policy formation/implementation and have also led to the methodological puzzle of what the real policy process is or what it is made up of. This paper attempts to review previous works on this subject and provide a suitable framework to link structural and individual perspectives in the study of state policy process. Traditional state policy process approaches such as Marxist theory, the Pluralist approach, the Elite approach and the Corporatism approach are discussed to demonstrate the methodological controversy of different analytical levels. In order to grasp a more comprehensive understanding of the policy process, the interests and interactions of the political actors, the institutional rules of game, the distribution of political resources, the power construct of choices, and political judgements should be considered in the research framework. It can be argued that the policy network approach (or network perspective) can be seen as an appropriate strategy to combine microscopic and macroscopic analysis of policy process.
\end{abstract}

Keywords: Policy formation, Policy process, Policy network, Structure and agency, Power exercise

\section{Introduction}

One old methodological issue is to determine what social reality is and what it consists of. Numerous social scientists have put effort into exploring the social phenomena, whether via the individual or structural perspective (Baber, 1991; Hollins, 1994; Sibeon, 1999). Is society a product of individuals' actions or a social construction? This question remains controversial and is unsolvable. For the policy elite to decide a policy outcome, there has to be a political system, an institutional arrangement and so on. They also have to be located in that system as policy elites. This is the sort of stance that a structuralist might make. However, it is also true that without individual stakeholders and their activities, there could be no such thing as policy proposals, politicians, interest groups and political systems. This is the sort of stance that a methodological individualist might make. These two approaches demonstrate two different kinds of explanatory strategies in social science one from structure to action, the other from action to structure.

There is little doubt that the studies of the policy process also have to use similar explanatory strategies to understand complicated policy processes that can be shaped by either individual action or structural pressure. In order for researchers of politics, public administration, and sociology to understand the nature of the policy process, the question of who decides policy formation and implementation is a key and unavoidable issue in the study of the policy process. Moreover, questions of policy formation/implementation are often translated into the language of power, a concept which theorists have debated for centuries. However, how to measure who has power to manipulate policy outcomes is always a challenge in studies of the policy process. State policy-making approaches are important ways of understanding the nature of the policy process and different approaches use distinct perspectives to understand the exercise of power in the policy process. As is widely agreed, the study of the policy process has to face the same debates of methodological issues as social science, especially to determine what the factors are that shape policy outcomes in the policy process. As the title mentioned, a policy outcome is regarded as society to discuss whether a policy outcome is a product of individual's action or structural pressure. The standpoint of this paper is not deflected to any one of them but stands on a synthesis of the two rival views.

This paper attempts to review the previous works and provide a suitable framework to link structural and individual perspectives in the study of state policy process. Studies on institutional change or policy formulation have long been the research domain of public policy students. Numerous significant works have been published to illustrate the themes such as "who governs" (Dahl, 1961) and "who gets what, when and how" (Lasswell, 
1990). These works attempt to demonstrate the nature of policy formation/implementation and examine how interdependent relationships of power can impact on policy outcome via their own perspectives (either methodological structuralism or individualism). To be persuasive, however, accounts of institutional change or policy formation should combine microscopic and macroscopic analysis. It is obvious that the stakeholders in a policy domain, on the one hand, are embedded in the specific institutional and political environments constraining their abilities and opportunities to advocate their interests. On the other hand, these stakeholders have strategies and tricks to change the rules and advocate their policy interests. The interests and interactions of the political actors, how the institutional rules of the game and the distribution of political resources and political power construct their choices and political judgements should be considered in the research framework.

In addition to the introduction, I divide my discussion into four sections: the first section is traditional policy process theories, focusing in particular on the role of the state, power distribution and exercise, and what their methodological stance is. The second section is a comprehensive discussion of relevant critiques in the debate of the two rival views in the policy process approaches. The third one is a discussion about a strategy that can combine structural and individual perspectives to understand the policy process and how these two perspectives can be linked by network perspective in studies of the policy process. Finally, I summarise the discussion draw conclusions.

\section{Traditional State Policy Process Approaches}

The use of power in the policy process is subtle and complex. Numerous researchers stand on their own points in order to understand how power is exercised or distributed in the policy process within a complicated political environment. Most attention will be briefly paid to four related theorists on this theme and their relevant works in explaining or interpreting the relationship between power and policy actors. The methodological challenges of these approaches will be discussed.

\subsection{Structural Approach: Top-down Approach}

There is no doubt that the first relevant approach is Marxist theory. Marxist approaches to power and the exercise of power in the state policy process are distinctive in focusing on its relations to economics, politics and ideologies (Jessop, 2001: 7). According to classical Marxist theory, the social structure of a capitalist society is essentially a class structure and the policy outcome of a state is just reflecting and maintaining the interests of the capitalist class (Hill, 2005: 40). Furthermore, Marxists have always claimed that state policy can, and should, be determined by the class interests of capitalists and their agents. The policy-making process can be depicted as reflecting the outcome of a struggle between the capitalists and working classes or partially determined by social and political forces operating within state structure itself (Laumann and Knoke, 1987: 6). With regard to the methodological perspective, the Marxist theory explanation of the state sees "economic imperatives" as a crucial influence in the state policy process - it claims, roughly, that the nature of economic structure is the essential foundational feature of the components of a state including legal and political structure. Marxist theory stands on the idea of the structural perspective, and sees structure constraints as a type of casual mechanism whereby the role of the state in the policy domain is explained by the requirements and rationality of the economic system. For instance, O'Connor (1973) classifies state intervention and its expenditure services in the interest of monopoly capital, and that the state is run by a class-conscious political directorate acting on behalf of monopoly capital class interests.

Marxists have conducted few empirical works that are more than abstract disputes to implicate the perspectives above in the explanation of policy output, and most of them addressed macro level issues in detailed historical case studies (Domhoff, 1978; Skocpol, 1979). These significant works emphasize the historical and structural force to shape the pattern of institutional change and policy output under dominant economic institutions, but none of these analyses track state policy-making at the level of policy stakeholders laying claims to governmental authority on behalf of their interests. As is widely known, the policy process in modern society is a complicated and various domain, and the role of the state does not only serve the interests of one dominant class. It also means that the simple proposition of a policy outcome cannot echo the whole phenomena of the policy process.

\subsection{Individual Perspective: The Bottom-up Approach}

\subsubsection{The Pluralist Approach}

The second traditional state policy process approach that should be discussed is pluralism, or pluralist theory. Pluralist accounts are offered as liberal or radical alternatives to Marxism (Bellamy, 2001: 17). Recent analyses have been concerned with the origins, prevalence, policy interests, resource endowments, and strategies of those 
associations and corporate actors as they seek to influence federal policy decisions in the U.S. (Laumann and Knoke, 1987: 7). In other words, the policy process in the national domain in general is seen as a wide and complex interaction between interests, actors and institutions rather than between institutions themselves. The pluralist school of thought in political science described and charted the theorem in which policies are developed in negotiations between public agencies and pressure groups organised into policy communities and the role of state has to be understood in the negotiation process among multiple stakeholders in policy domains.

Pluralists have been criticized for having an overly optimistic view of the diverse distribution of power (Bachrach and Baratz, 1962; Lukes, 1974). In fact, a perfect environment of equal power distribution has little possibility of existing in a real political process and most policy outcomes are manipulated by a few powerful policy elites. Moreover, the pluralist explanation ignores not only the role of the state in the policy process but also the power of the institutions, which allow the state the authority to regulate the behaviours of policy stakeholders. In spite of the fact that pluralist theory reflects some of the social and political phenomenon of democratic countries, especially in the U.S., the emphasis on interest and group interaction provides a limited research tool to examine the policy process in modern society and also to make an ambiguous causal explanation between policy outcome and the actions of interest groups.

\subsubsection{The Elite Approach}

The third traditional state policy approach is the elite approach, which arose from similar dissatisfaction with liberal democracy and the pluralist theory. However, compared to pluralist theory, the elite perspective assumes that the power is based on the unequal distribution of resources and that public has little influence on policy outcomes. Mills (1956) draws attention to institutional position as a source of power, and concludes that the power elites occupying key positions in government, business and the military are dominant in the policy process of the American political system. Mills' work takes the individual as its unit of analysis, and suggests that the exercise of power is revealed in the overlap and connection between the leaders of these organisations (Laumann and Knoke, 1987: 6). Thus, compared to Marxist and Pluralist theories, the elite approach provides another different alternative to identify who has power and how power is exercised in policy domains via analysing the interactions among political elites occupying the key positions of important organisations.

Though elite theory resolves the analytical problem of pluralist theory, it creates another bias of the power exercise in the policy process. First, there are difficulties in specifying the mechanisms by which power is measured and the techniques used to hold it (Hill, 2005: 38). Second, most research in elite theory only focuses on the analysis of powerful individuals in important organisations. However, this endeavour neglects the fact that the nature of power exercise is also revealed in inter-organisational exchange and the influence of interest groups should be one of factors important in the resulting policy outcomes (Laumann and Knoke, 1987: 7). In order to cope with the critique, some researchers have made efforts to reconcile elitism and pluralist democracy to consider the influence of both individual and organisational levels in policy domains.

\subsubsection{The Corporatism Approach}

Finally, the fourth traditional state policy approach is corporatist theory or so-called corporatism. Like other traditional approaches, corporatist theory is seen as a system of interest representation and stands on methodological individualism. Schmitter's definition stressed the "intermediation" function that groups play in corporatist societal system in which "the constitute units are organised into a limited number of singular, compulsory, non-competitive, hierarchically ordered and functionally differentiated categories" (Schmitter, 1979: 93). In general, corporatism refers to a set of institutional arrangements for policy making and economic governance. It involves a model of political decision making characterised by a negotiated approach to key economic strategies by the major economic agents representing labour and capital. Thus, the corporatist mechanism has been seen as a kind of effective participation of labour organisations in policy formulation and implementation and regulation of economic activity in Europe. But in the United States, most scholars agree that the American political regime lacks corporatist attributes (Wilson, 1982). The explanatory shortage might occur in other countries outside Europe.

\section{The Theoretical Debate: Is Policy a Product of Individuals' Action or Structural Pressure?}

Let us look in more detail at the structure-agency debate on policy process studies. The methodological problem of this issue in the studies of the policy process is the problem of "level-of-analysis" (see Figure 1). As has been mentioned above, the top-down approach can be applied for an explanatory strategy in Figure 1 and the causal relationship can be identified that structure (both in the institutional and political context) shapes policy outcome. For example, Marxist theory states that the policy outcome is the product of structural pressure and every stakeholder in the policy domain has to follow the rules of capitalism. Although structural pressure can shape a 
scenario constraining the actors' behaviours, this approach ignores the individuals' recognition of their political context and institutional arrangement. There is no doubt that individuals have their own preferences and individuals' actions might not just be determined by structure. Moreover, we have to consider the possibility that individuals under environmental constraints can change the rules of the game.

Figure 1

At the individual level, therefore, the policy process, like the bottom-up approach, seen as a product of individuals' actions is one of the main streams regarded in the interest group approach such as pluralism, elitist theory and corporatism. The main stream is a significant label of the policy process in democratic countries such as the U.S., the UK and other Western countries. Most theorists in the area are concerned with the idea that the political phenomena of the policy process in these countries is an interactive game of multiple stakeholders. As Jon Elster (1989: 19) indicates, the elementary unit of social life is the individual human action. According to this view, the main unit of policy process analysis is an individual who is self-interested and action-free, but there is no doubt that the stance ignores the influence of the political environment and the institutional context, which can shape the chance and strategy of actors under the specific game rules. More specifically, policy process is embedded in distinct institutional and political contexts and different policy domains have different game rules and stakeholders. It will become an under-socialised approach concerned too much with individuals' function and the influence of the policy process.

The traditional approaches dissected above are all relevant to the interaction between policy stakeholders, structure and the role of state in policy domains. There is no doubt that these approaches, both structural and individual perspectives, are biased in their understanding of the nature of the policy process in modern society. In order to eschew both pluralistic individualism and Marxist class structuralism approaches, this paper views policies as resulting from conflicts and contradictions among multiple policy stakeholders embedded in the institutional and political environments rather than only reflecting the class interests or clarity of a limited bargaining-negotiation system. From a methodological stance, this paper lies in the overlapping area in Figure 1. Obviously, the policy process in modern society should be a complicated political scenario. It also means that a more suitable and flexible perspective, such as the policy network approach, should be applied to understand the nature of power-exchange and the bargaining-negotiation relationship between official and unofficial stakeholders in the policy domain.

\section{A Strategy to Link Structure and Agency: A Network Perspective}

\subsection{The Modern Policy Environment and the Emergence of Policy Networks}

Recently, government has faced a more fragmented governance environment. Traditional methods of dealing with problems, which often explain complex issues as intellectual design questions and approach them by giving research and science a central role, are no longer enough. As has been mentioned above, the nature of the policy process is faithfully involved in multiple policy stakeholders and their interest-exchange relationships. The decisions by policy makers to exploit this increasingly complex and interdependent environment through these stakeholders are inconsistent. However, network is a portable concept that can be applied to any public arena. The study of policy networks offers more insight into how policy is made and implemented than traditional policy process approaches. Thus, a policy network approach providing a more flexible explanation can be used to understand the complex nature of the policy process in modern society.

The concept of networks in the analysis of public policy processes first emerged in the mid-1970s and early 1980s (Klijn, 1997: 16; John, 2004: 140). In the past three decades, a considerable amount of effort has been expanded by political scientists and researchers of public administration in trying to understand the structure of stakeholders' interaction in policy domains and the reasons for policy failure in the U.S., the UK, and other European countries (Heclo, 1978; Richardson and Jordan, 1979; Rhodes, 1990; Marsh and Rhodes, 1992; Kickert, Klijn and Koppenjan, 1997; Marsh, 1998). The concept of network is an appropriate metaphor describing the strategic interaction between Congress, bureaucrats, the president, the courts, the people, the media, interest groups, and all other possible actors playing important roles in policy domains.

In the U.S., numerous researchers have used metaphors like "iron triangle", "whirlpool" or "private government" to describe the sub-government system as an important political decision-making mechanism in earlier U.S. government (John, 2004: 142). Moreover, Heclo's popular work on "issue networks" provides a more fluid and changeable form of political relationships in the U.S. government and his significant work also had roused subsequent endeavours focusing on the issue of fragmented governance mechanism in the U.S.

In Britain, network concept dominated British policy studies for much of the 1980s and 1990s and in particular 
influenced three UK Economic and Social Research Council research programmes (John, 2004: 143-144). It is worth noting that various significant efforts have been made to understand multiple policy domains such as agriculture (Smith, 1990, 1991); water (Richardson, Maloney and Rudig, 1992); sub-national government (Gray, 1994); community care (Hunter and Wistow, 1987), government-industry relations (Wilks and Wright, 1987) and inter-governmental relationship (Rhodes, 1992).

In EU studies, the concept of policy networks has been seen as a new form of governance (Kenis and Schnider, 1991; Kooiiman, 1993). These leading EU works attempt to use the idea of policy network to facilitate the co-ordination and co-governance relationships between multiple agents at the cross-national or domestic levels. As has been discussed above, it can be concluded that policy network approach has been popularly applied in studies of the policy process in modern democratic society.

The concept of policy network is used to indicate patterns of relationships between interdependent actors involved in processes of public policy making (Kickert, Klijn and Koppenjan, 1997: 6). There is no doubt that an independent relationship is the most important characteristic of policy networks and many theoretical foundations such as the "power/resource dependence" approach (Benson, 1975; Rhodes, 1988, 1990) or the "idea" approach (Sabatier and Jenkins-Smith, 1993) indicate that all actors in a policy domain cannot achieve their own interests and goals without others' assistance because they need others' resources and support or share the languages and ideas to do so. It also means that the policy problem nowadays is frequently non-hierarchical and has been become more complex in democratic countries and complicated problems require a combination of various resources and ideas owned by different actors. Hence, it is obvious that policy games are created when actors recognise that they have to depend on one another for the realisation of their objectives and in these cases there are mutual dependencies that are not equally divided across these policy stakeholders. It can be concluded that the capability to mobilise resources and consolidate policy coalitions is the most important means of manipulating policy processes in policy networks.

\subsection{Network as a Way to Link Structure and Agency in the Policy Process}

As mentioned in the previous section, there are two important characteristics of the policy process in a policy network environment. The first one is that no stakeholders can achieve their goals without other's help such as information, finance, and resource-exchange. The second is that the exercise of power is the most important element in the policy process. As noted above, it can also be said that the exercise of power or the influential pathways in the policy process are absolutely identified by the network relationships between two or more policy makers rather than property or attribute that is inherent in an individual or group. It also means that power relationships are asymmetrical actual or potential interactions in which one social actor exerts greater control over another's behaviour. Besides, more specifically, if we are concerned more with communication and information-exchange in policy processes, the influence occurs when one actor intentionally transmits information to another, altering the latter's actions from what would have occurred without the information (Parsons, 1963; Knoke, 1994: 3). This also means that influence is possible only when communication occurs between social actors. One actor must transmit a message to another, and the second actor must receive, decode, interpret, and react to that message. If we are concerned more with Dahl's definition of power, this also shows that power is a relationship between one social actor and another within a specific situation. In other words, influence can also be seen as the relational dimension of power because a communication channel must exist between influencer and influencee. The basic units of any complex policy network system are not individuals, but positions or roles occupied by social actors and the relations or connections between these positions (Knoke, 1994: 3).

How is the network approach a strategy for linking methodological individualism and structuralism in the studies of policy process? As can be seen in Figure 2, the causal relationship of the structural perspective in policy process studies can be identified as pathway four. On the other hand, the individual perspective can be specified via pathway three, which shows individuals' action strategies influence on policy outcomes. It is obvious that the structural approach not only ignores individual bases of explanation in the policy process, but also that the agent approach neglects the structural factor that can shape individuals' behaviour. To be persuasive, however, accounts of policy formation/implementation should combine both structural and individual perspectives because the stakeholders in policy domains are embedded in the political and institutional contexts. Of course, before the casual relationship between action strategy and policy outcome can be identified, institutional and political structure has influence on an actor's preference and gives him or her change and boundary to identify their interests and strategies. But how can we understand the context before processing the study? The network perspective, emphasising structural relationships as its key orienting principle (Knoke and Yang, 2008: 8), is a strategy to link pathways one, two and three. 
Figure 2

As Granovetter (1985) points out, under-and over-socialised accounts are paradoxically similar in their neglect of ongoing structures of social relations, and a sophisticated account of individual action must consider its embeddedness in such structure. The network approach is a method to build a bridge between the structural constraints and individual action in social science and can provide measures of the structural constraints of actors depending not only on their own relations but also on the way other actors are related. Embedding actors within the set of their interactions allows for insight into the distribution of power and the effective influence of social and political actions. With regard to the methodological stance of the network perspective, two important themes should be noticed. First, the methodological level of the network approach can be identified at the meso-level (Rhodes, 1997; Marsh, 1998) and the unit of analysis is not individual but tie. The specification of the role of networks for different participation in an attempt to show that affecting individual preference is a major function of networks. Second, networks are a powerful conceptual tool for linking the structural location of actors, their individual preferences, and their actions, for bridging the micro/macro gap, and for connecting structure and agency (Emirbayer and Goodwin, 1994; Tilly, 1997). The reason is that the network approach works to describe underlying patterns of social structure, explaining the impact of such patterns on behaviour and attitudes (Wellman, 1999: 44).

To sum up, social scientists study power relations among people, organizations and nations, and it is also the most important characteristic of policy process studies in modern society. Policy network analysis has been a research approach in public process studies for many years and offers a description of how policy decision processes are organised, but does not provide any explanation of why they are organized in that way (Hill, 2005: 74). Due to the difficulty of measuring networks, policy network analysis has often been treated as a metaphor, a conceptual scheme, or a management technique (Milward and Provan, 1998: 397) but there is no doubt that the network perspective provides not only a useful alternative to understand the policy process in modern society but also a strategy to build a bridge between structural and agent perspectives.

\section{Conclusion}

In the studies of the policy process, the structuralists have tended to ignore the possibility that actors' attributes, cognitions or personalities shape the game rules, but in contrast, so do individualists. As has been mentioned above, the structural perspective such as Marxist theory, argues that state policies are determined by the class interests of capitalists and their agents but the reality of modern capitalist countries is not all manipulated and controlled by these capitalists. Moreover, as the main characteristic of democratic countries, interest groups and their actions play an important role in influencing policy outcomes in the policy process, but these parallel approaches, such as pluralist theory, elitist theory and corporatism, all neglect the structural and institutional contexts in which the stakeholders are embedded. It can be concluded that the policy process and outcome should not be so determined by a simple causal explanation of either top-down or bottom-up logic.

The policy process in modern society should be complex, dynamic and varied. It also means that researchers are operating in a dynamic environment among a range of stakeholders who may have very different interests and different levels of influence in policy domains. To avoid the bias of explanation, a research tool that can link microscopic and macroscopic analysis is necessary for studies of the policy process in modern society. The policy network approach, concerned with the nature of the policy process, is an uncertain structure shaped by resource-exchange and communicative relationships among multiple elites. It can be seen that the network concept in the policy process concerns not only more structural factors than the pluralist, the elitist and the corporatism theories can, but also more individual factors than the Marxist theory can.

In conclusion, there is no doubt that the old puzzle of structure-agency dualism is still ongoing today and any effort to solve the problem is futile. This paper is just a preliminary exploration to seek an alternative way of replacing traditional policy process approaches in policy process studies and to try to offer a way to link top-down and bottom-up approaches. In order to gain more understanding of reality, more endeavours to develop network approach in policy process studies should be made.

\section{Acknowledgement}

Thanks are due to the editor, editorial board and two reviewers for important suggestions. I have benefited from the comments of Professors Ian Shaw and Lina Song at the University of Nottingham, UK.

\section{References}

Baber, Z. (1991). Beyond the Structure/Agency Dualism: An Evaluation of Gidden's Theory of Structure. Sociological Inquiry 61 (2), 219-230. 
Bachrach, P., \& Baratz, M. (1962). Two Faces of Power. The American Political Science Review, 56, 947-952.

Bellamy, R. (2001). Development in Pluralist and Elite Approaches. In K. Nash \& A. Scott (Eds.), The Blackwell Companion to Political Sociology. Oxford: Blackwell Publishers Ltd.

Benson, J. K. (1975). The Interorganisational Network as a Political Economy. Administrative Science Quarterly, 20, 229-249.

Benton, T., \& Craib, I. (2001). Philosophy of Social Science: the Philosophical Foundations of Social Though. Basingstoke: Palgrave.

Coleman, J. S. (1990). Foundations of Social Theory. Cambridge: Harvard University Press.

Dahl, R. A. (1961). Who Governs? New Heaven: Yale University Press.

Domhoff, G. W. (1978). The Powers That Be: Process of Ruling-Class Domination of America. New York: Vintage Books.

Elster, J. (1989). Introduction In J. Elster \& K. O. Moene (Eds.), Alternatives to Capitalism (pp. 1-35). Cambridge: Cambridge University Press.

Emirbayer, M., \& Goodwin, J. (1994). Network Analysis, Culture, and the Problem of Agency. American Journal of Sociology, 99 (6), 1411-1454.

Granovetter, G. (1985). Economic Action and Social Structure: The Problem of Embeddedness. American Journal of Sociology, 91 (3), 481-510.

Helco, H. (1978). Issue Networks and the Executive Establishment In A. King (Ed.), The New American Political system (pp. 87-124). Washington, D.C.: American Enterprise Institute for Public Policy Research.

Hill, M. (2005). The Public Policy Process. Essex: Pearson Education Limited.

Hollis, M. (1994). The Philosophy of Social Science : An Introduction Cambridge: Cambridge University Press.

Gray, C. S. (1994). Government Beyond the Centre: Sub-national Politics in Britain. Macmillan Basingstoke.

Jessop, B. (2001). Developments in Marxist Theory. In K. Nash \& A. Scott (Eds.), The Blackwell Companion to Political Sociology. Oxford: Blackwell Publishers Inc.

John, P. (2004). Policy Network. In K. Nash \& A. Scott (Eds.), The Blackwell Companion to Political Sociology. Oxford: Blackwell Publishing.

Hunter, D. J., \& Wistow, G. (1987). Community Care in Britain: Variations on a Theme. London: King Edward's Hospital Fund for London.

Kenis, P., \& Schneider, V. (1991). Policy Networks and Policy Analysis: Structuring A New Analytical Toolbox. In B. Marin \& R. Mayntz (Eds.), Policy Network: Empirical Evidence and Theoretical Considerations (pp. 25-59). Frankfurt am Main: Campus Verlag.

Kickert, W. J. M., E.-H. Klijn \& J. F. M. Koppenjan (Eds.) (1997). Managing Complex Network: Strategies for the Public Sector. London: SAGE publication

Klijn, E. H. (1997). Policy Networks: An Overview. In W. J. M. Kickert, E.-H. Klijn \& J. F. M. Koppenjan (Eds.), Managing Complex Network: Strategies for the Public Sector (pp. 14-34). London: Sage.

Knoke, D., \& Yang, S. (2008). Social Network Analysis. London: Sage.

Kooiiman, J. (Ed.). (1993). Modern Governance: New Government-Society Interactions. London: SAGE.

Lasswell, H. D. (1936). Who Gets What, When and How. Cleveland: Meridian Books.

Laumann, E. O., \& Knoke, D. (1987). Organizational State: Social Choice in National Policy Domains. Medison: University of Wisconsin Press.

Lukes, S. (1974). Power: A Radical View. London: MacMillan Press.

Marsh, D. (1998). The Development of the Policy Network Approach. In D. Marsh (Ed.), Comparing Policy Network. Buckingham: Open University Press.

Marsh, D. \& Rhodes, R. A. W. (1992). Policy Network in British Government. Oxford: Clarendon Press.

Mills, C. W. (1956). The Power Elite. New York: Oxford University Press.

Milward, H. B., \& Provan, K. G. (1998). Measuring Network Structure. Public Administration, 76, 387-407.

O'Connor, J. (1973). The Fiscal Crisis of the State. New York: St. Martin's Press. 
Parsons, T. (1963). On the Concept of Influence. Public Opinion Quarterly, 27, 37-62.

Rhodes, R. A. W. (1988). Beyond Westminster and Whitehall: The sub-Central Governments of Britain. London: Unwin-Hyman.

Rhodes, R. A. W. (1990). Policy Networks: A British Perspective. Journal of Theoretical Politics, 2, 292-316.

Rhodes, R. A. W. (1992). 'The Europeanisation of Sub-central Government: the case of the UK', in C. Fletcher and C. Walsh (Eds.) The Impact of Federalism on Metropolitan Strategies in Australia (pp. 72-79). Canberra: Federalism Research Centre, Australian National University.

Rhodes, R. A. W. (1997). Understanding Governance: Policy Networks, Governance. Reflexivity and Accountability. Buckingham: Open University Press.

Richardson, J. J., \& Jordan, A. G. (1979). Governing Under Pressure: the Policy Process in a Post-parliamentary Democracy. Oxford: Martin Robertson.

Richardson, J. J., Maloney, W. A., \& Rüdig, W. The Dynamics of Policy Change: Lobbying and Water Privatisation. In H. T. A. Bressers \& L. J. O’Toole (Eds.), International Comparative Policy Research: Preparing a Four-Country Study on Water Quality Management (pp. 127-153). Enschede: Universiteit Twente.

Sabatier, P. \& Jenkins-Smith, H. (Eds.). (1993). Policy Change and Learning: An Advocacy Coalition Approach. Boulder, CO: Westview Press.

Scharpf, F. W., \& Hanf, K. (1978). Interorganizational Policy Making. Limits to Coordination and Central Control (Vol. 1). London: Sage.

Schmitter, P. C. (1979). Intermediation and Regime Governability in Contemporary Western Europe and North America. In P. C. Schmitter \& G. Lehmbruch (Eds.), Trends Toward Corporatist Intermediation (pp. 285-327). London: Sage.

Sibeon, R. (1999). Agency, Structure and Social Chance as Cross-Disciplinary Concepts. Politics, 19 (3), 139-144.

Skocpol, T. (1979). States and Social Revolutions. New York: Cambridge University Press.

Smith, M. (1990). The Agricultural Policy Network: Maintaining a Closed Relationship. In R. A. W. Rhodes \& D. Marsh (Eds.), Policy Networks in British Government. Oxford: Clarendon Press.

Smith, M. J. (1991). From Policy Community to Issue Network: Salmonella in Eggs and the New Politics of Food. Uxbridge: Department of Government, Brunel University.

Tilly, C. (1997). Parliarmentarization of Popular Contention in Great Britain, 1758-1834. Theory and Society, 26, 245-273.

Wang, G. X. (2005). The Core Position and Methodological Mismatch of Policy Network Research in the Field of Public Administration. Journal of Policy Studies, 5, 61-102.

Wellman, B. (1999). From Little Boxes to Loosely Bounded Networks: the Privatization and Domestication of Community. In J. L. Abu-Lughod (Ed.), Sociology for the Tewnty-First Century (pp. 94-114). Chicago: University of Chicago Press.

Wilks, S., \& Wright, M. (1987). Comparative Government - Industry Relations: Western Europe, the United States and Japan. Oxford: Clarendon Press.

Wilson, F. L. (1982). Alternative Models of Interest Intermediation: the Case of France. British Journal of Political Science, 12, 173-200. 


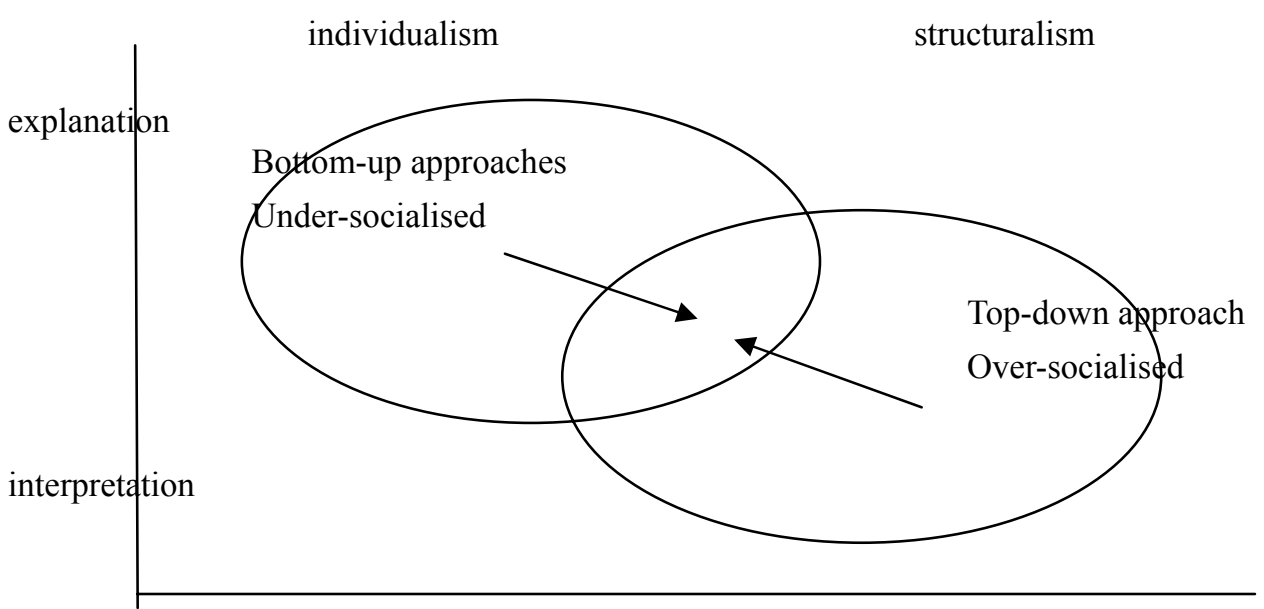

Figure 1. The Approaches in Policy Process Studies (dependent variable: policy outcome)

Source: modified from Hollins, 1994: 19

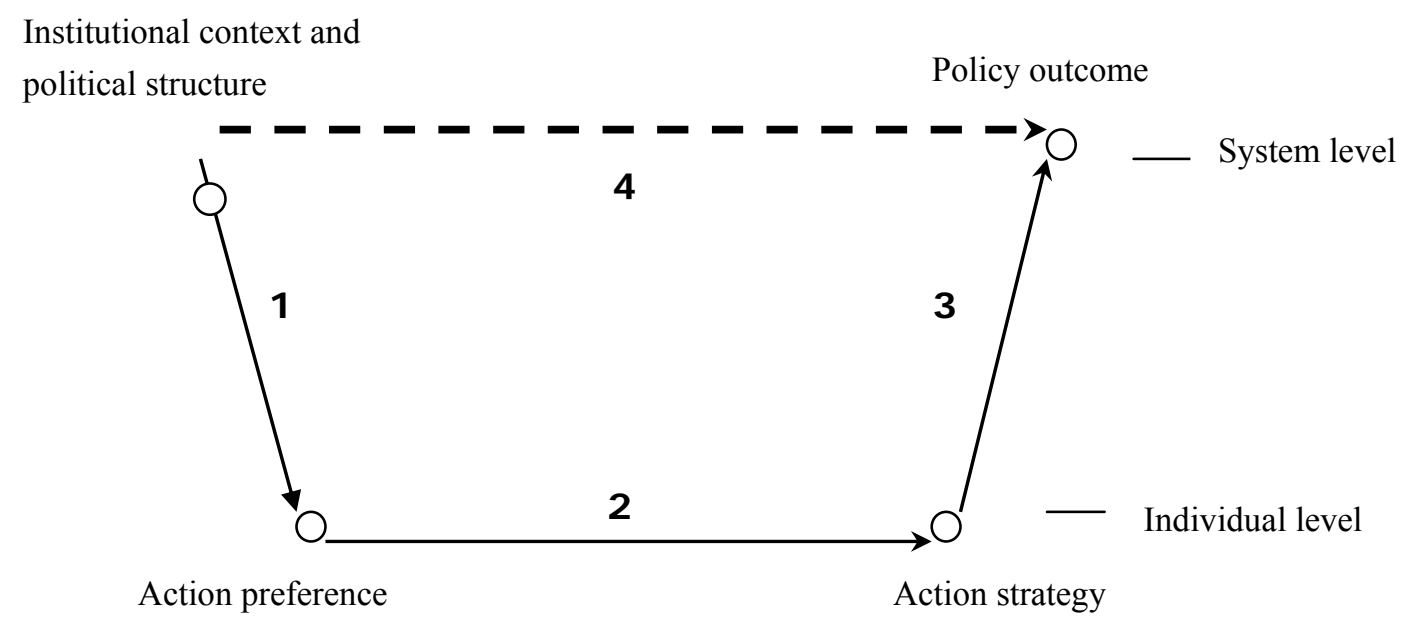

Figure 2. Level of Analysis in Policy Process

Source: modified from Coleman, 1990: 8 